\title{
Combining Ability and Heterosis of Selected Grain and Forage Dual Purpose Sorghum Genotypes
}

\author{
Sally Chikuta ${ }^{1,2}$, Thomas Odong ${ }^{1}$, Fred Kabi ${ }^{1} \&$ Patrick Rubaihayo ${ }^{1}$ \\ 1 Department of Agricultural Production, School of Agricultural Sciences, College of Agriculture and \\ Environmental Sciences, Makerere University, Kampala, Uganda \\ ${ }^{2}$ Department of Agriculture, Ministry of Agriculture, Chibombo District, Zambia \\ Correspondence: Sally Chikuta, Department of Agricultural Production, School of Agricultural Sciences, College \\ of Agriculture and Environmental Sciences, Makerere University, P.O. Box 7062, Kampala, Uganda. E-mail \\ sallychikuta@yahoo.com
}

Received: September 21, 2016

Accepted: November 26, 2016

Online Published: January 15, 2017

doi:10.5539/jas.v9n2p122

URL: http://dx.doi.org/10.5539/jas.v9n2p122

Support for this research was made possible through a capacity building competitive grant Training the next generation of scientists provided by Carnegie Cooperation of New York through the Regional Universities Forum for Capacity Building in Agriculture (RUFORUM).

\begin{abstract}
Sorghum is an important food and feed source in mixed crop-livestock production systems where its dual usage is a preferred option, especially among the resource poor small-scale farmers. Attempts to improve fodder quality traits in maize have been at the expense of grain traits and vice versa, but other studies demonstrated that it was possible to select for high stem biomass without compromising the improvement of grain yields in sorghum. As a follow up to this effort, this study was undertaken to estimate the combining ability of grain and forage sorghum genotypes and determine heterosis for several traits as a criteria for improving dual purpose sorghum cultivars. Four grain and four forage sorghum cultivars were crossed to generate 23 crosses following the half diallel mating design scheme at Makerere University Agricultural Research institute Kabanyolo (MUARIK) in 2013. The crosses were evaluated at three locations in Uganda during two rainy seasons of 2014. Data were taken and analysed on leaf area, leaf-stem ratio, plant height, seed weight, grain yield, and biomass. Results indicated that the gene action for the traits under observation was controlled by both additive and non additive genetic effects. Majority of the parental lines had significant GCA estimates for all traits except line 20 for grain yield, lines 22 and 34 for plant height, line 35 for leaf-stem ratio, and line 22 for days to flowering. Significant $(\mathrm{P} \leq 0.05)$ SCA estimates were prominent in most of the individual parental combinations for all traits except leaf area and leaf-stem ratio indicating the role of dominance gene action. Bakers ratio and heritability coefficients were $>52 \%$ for biomass, flowering duration and plant height indicating that genetic gains can be achieved by conventional breeding for the three traits. Heterosis in grain yield and biomass over both the mid and better parents was shown by more than half of the crosses studied. This study suggested that both inter and intra allelic interactions were involved in the expression of the traits.
\end{abstract}

Keywords: biomass, gene action, grain yield, heterosis, heritability coefficients

\section{Introduction}

Sorghum (Sorghum bicolor (L) Moench) is an important food and feed crop of dry land agriculture because of its wide range of adaptability to various agro-ecological conditions. It is a self pollinating, diploid $(2 n=2 x=20)$ with a genome $25 \%$ of the size of maize or sugar cane (Rai et al., 1999). Although sorghum is the fifth most important cereal crop in the world after wheat, rice, maize and barley, it is ranked second following maize in Africa (Kenga et al., 2005). In developing countries, sorghum is primarily used as a food crop (Bawazir, 2009), and has been improved to a great extent for grain (Williams et al., 1997). However, in the developed countries, it is used primarily as a feed crop (Chakauya et al., 2006). Given that crop- livestock production systems are the most common form of land use in semi-arid areas of Africa (Mativavarira et al., 2011) among the resource poor 
small scale farmers who rely on crop residues as livestock feed (Sibanda et al., 2011), genetic improvement of this crop for dual usage as grain and fodder is cardinal.

Traits like grain and fodder yield are governed by polygenes with complex gene action (Jain \& Patel, 2014), hence understanding the gene action would help plant breeders in selecting appropriate breeding methods. In addition, efficient transmission of desirable genes from selected parents to their progeny needs firm knowledge about gene action (Falconer \& Mackay, 1996). Combining ability studies provide useful information regarding the selection of suitable parents for effective hybridization programmes and indicate the nature and magnitude of various types of gene action involved in the expression of quantitative characters (Bernardo, 2014). The process also helps in ensuring accumulation of desirable unfixable or fixable gene effects (Nadarajan \& Gunasegaram, 2005). General combining ability (GCA) was described by Falconer (1989) as the mean performance of a genotype when crossed with a series of other genotypes. The performance of a cross can deviate from the average general combining ability of two parental lines due to genetic effects that are specific to that cross and this deviation is referred to as specific combining ability (SCA) (Bernardo, 2014). The differences in GCA are mainly due to additive effects and higher order additive interactions while differences in SCA may be attributed to non-additive gene effects. The analysis of combining ability, therefore, allows broad inferences on the nature of gene effects for a trait under selection. Analysis of diallel data partitions variation into GCA of the parents and SCA of the crosses (Yan \& Hunt, 2002). The estimation of GCA effects helps to identify good combiners which may be hybridised to exploit heterosis and select better crosses for further breeding (Singh \& Chaudhary, 1985). The grain and fodder yields are primary traits targeted for improvement of dual purpose sorghum productivity through exploitation of heterosis. The desirable tendency is to have progeny that perform better than the parental lines for traits of interest.

This study was undertaken to estimate the general and specific combining ability and heterosis of different grain and forage sorghum genotypes in $F_{1}$ combinations for grain yield, biomass and related traits as a criteria for developing superior dual purpose sorghum cultivars.

\section{Materials and Method}

\subsection{Planting Materials}

Eight sorghum genotypes were selected based on their performance for high grain and fodder yield in a prior diversity study and used as parental lines in this study. The genotypes comprised four grain and four forage sorghum cultivars which were crossed to generate 23 crosses following the half diallel mating design scheme (Griffing, 1956) at Makerere University Agricultural Research institute Kabanyolo (MUARIK) in 2013 season B.

\subsection{The Experiment and Site Descriptions}

The 23 crosses and parents were sown in randomized complete block design with three replications at MUARIK in 2014 (Season A and B), Mbarara Zonal Agricultural Research Station in 2014 season B and National Semiarid Agricultural Research institute (NaSARRI) in 2014 season B. MUARIK is located at $0^{\circ} 28^{\prime} \mathrm{N} ; 32^{\circ} 37^{\prime} \mathrm{E}$ and is $1200 \mathrm{~m}$ asl with mean daily temperatures of $20^{\circ} \mathrm{C}$. NaSARRI is located at $1^{\circ} 39^{\prime} \mathrm{N} ; 33^{\circ} 27^{\prime} \mathrm{E}$, and is 1038 masl with mean daily temperatures of $24^{\circ} \mathrm{C}$ andMbarara is located at $0.6^{\circ} 13^{\prime} \mathrm{S} ; 30^{\circ} 65^{\prime} \mathrm{E}$ and is 1445 masl. Each genotype was planted in four $3 \mathrm{~m}$ rows, $0.6 \mathrm{~m}$ apart with an intra row spacing of $0.3 \mathrm{~m}$. A distance of $1 \mathrm{~m}$ was left between plots and $2 \mathrm{~m}$ between replications.Data was collected on days from planting to $50 \%$ flowering, grain yield, 1000 seed weight, plant height, above ground biomass, Leaf-stem ratio and Leaf area (Leaf number $\times$ Leaf length $\times$ Leaf width $\times 0.75$ ) following recommended sorghum descriptors (IBPGR/ICRISAT, 1993). Number of days from planting to flowering for each genotype were recorded when half the number of plants in the plots had flowered. To estimate plant height, the height of ten randomly selected plants was measured at the $50 \%$ plant flowering stage from the ground to the panicle tip. Leaf-stem ratio was obtained by destructive sampling at the soft dough stage and stripping leaves off the stems of five randomly selected plants. Each sample was oven dried at $65{ }^{\circ} \mathrm{C}$ for 72 hours and weighed to compute the ratio.

\subsection{Data Analysis}

The data were first analysed separately for each location and a combined analysis over locations was computed. Analysis of variance was done prior to computing combining ability estimates according to Griffing's model I (fixed model for parental effects), method 4 (exclusion of parents and reciprocal F1's) diallel analysis procedures (Griffing, 1956). Important combining ability effects were revealed through F-tests, the restrictions imposed on combing ability estimates were: $\mathrm{Sg}_{\mathrm{i}}=0$ and $\mathrm{Ss}_{\mathrm{ij}}=0$, for all GCA and SCA effects respectively (Bernardo, 2014). These combining ability estimates were tested for deviation by using two tailed t-tests as described by 
Singh and Chaudhary (1985). The combining ability ratio (Baker's ratio) $2 \sigma_{\text {gca }}^{2}\left(2 \sigma_{\text {gcat }}^{2} \sigma_{\text {sca }}^{2}\right)$, was derived following Baker (1978) while broad and narrow sense coefficients of genetic determination were calculated following Abney et al. (2000). Mid and better parent heterosis were estimated for days to flowering, leaf stem ratio, grain yield and biomass following method of Singh and Narayanan (1993).

Combining ability Model:

$\mathrm{Y}_{\mathrm{ij}}=\mu+\mathrm{g}_{\mathrm{i}}+\mathrm{g}_{\mathrm{j}}+\mathrm{s}_{\mathrm{ij}}+\mathrm{e}_{\mathrm{ij}}$

Where, $Y_{i j}=$ mean of the $F 1$ resulting from crossing $i^{\text {th }}$ parent and $j^{\text {th }}$ parent, $\mu=$ population mean, $g_{i}=$ GCA effect of $i^{\text {th }}$ parent, $g_{j}=$ GCA effect of $j^{\text {th }}$ parent, $s_{i j}=$ SCA effect of the cross between $i$ and $j$ parent. The GCA of the $\mathrm{i}^{\text {th }}$ line in the diallel can be defined as the mean performance of the crosses having $\mathrm{i}^{\text {th }}$ line as one of its parents. The SCA of the $i^{\text {th }}$ and $j^{\text {th }}$ cross in array can be defined as the deviation in mean of this cross from the mean of that array.

Narrow Sense Coefficient of Genetic Determination (NSCGD) $\sim \mathrm{h}^{2}=2 \sigma_{\text {gca }}^{2} /\left(2 \sigma_{\text {gca }}^{2}+\sigma_{\text {sca }}^{2}+\sigma_{\mathrm{e}}^{2}\right)$

Broad Sense Coefficient of Genetic Determination (BSCGD) $\sim \mathrm{H}^{2}=2 \sigma_{\text {gca }}^{2}+\sigma_{\text {sca }}^{2}\left(2 \sigma_{\text {gca }}^{2}+\sigma_{\text {sca }}^{2}+\sigma_{\mathrm{e}}^{2}\right)$

Where, $\sigma$ is the variance of the respective subscript.

Mid-parent heterosis $(\%)=\left(\mathrm{F}_{1}-\mathrm{MP}\right) / \mathrm{MP}$

Better-parent Heterosis $(\%)=\left(\mathrm{F}_{1}-\mathrm{BP}\right) / \mathrm{BP}$

Where, $F_{1}$ is the performance of the cross, MP is the average performance of the parents and $\mathrm{BP}$ is the performance of the better parent.

All data analysis was done using GenStat statistical package (VSN International, 2011).

\section{Results}

\subsection{Performance of Parental Lines and Crosses across Three Locations}

The results from the analysis of variance and heritability estimates of parental lines and crosses across the three locations are presented in Table 1 . The effects of genotypes were significant $(P \leq 0.001)$ for all traits. These variations in all traits except leaf area were mainly due to the additive gene effects of the parents as indicated by the significant $(\mathrm{P} \leq 0.05)$ GCA mean squares. However, significant $(\mathrm{P} \leq 0.05) \mathrm{SCA}$ effects were also observed for leaf-stem ratio, grain yield and biomass implying that these traits were controlled by either or both additive and non additive gene actions. The effects of locations were significant $(\mathrm{P} \leq 0.05)$ for leaf area, leaf-stem ratio, plant height, grain yield and biomass. All the interaction effects were significant $(\mathrm{P} \leq 0.05)$ for all traits except GCA $\times$ Location effect for grain yield.

The baker's ratio and narrow sense coefficient of genetic determination (NSCGD) for all traits ranged between 22 to $87 \%$ while the broad sense coefficient of genetic determination for heritability (BSCGD) was high for all traits ranging between 66 to $99 \%$. 
Table 1. Analysis of variance and heritability coefficients for seven traits measured across three locations in Uganda

\begin{tabular}{|c|c|c|c|c|c|c|c|c|}
\hline Sources of Variation & $\mathrm{DF}$ & $\begin{array}{l}\text { Days to } 50 \% \\
\text { Flowering }\end{array}$ & $\begin{array}{l}\text { Leaf area } \\
\left(\mathrm{m}^{2}\right)\end{array}$ & Leaf-stem Ratio & $\begin{array}{l}\text { Plant height } \\
\text { (m) }\end{array}$ & $\begin{array}{l}1000 \text { Seed Wt } \\
(\mathrm{g})\end{array}$ & $\begin{array}{l}\text { Grain Yld } \\
\left(\text { ton } \mathrm{ha}^{-1}\right)\end{array}$ & $\begin{array}{l}\text { Biomass } \\
\left(\text { ton } \mathrm{ha}^{-1}\right)\end{array}$ \\
\hline Replications & 2 & $5.11 \mathrm{~ns}$ & $0.15 \mathrm{~ns}$ & $0.00 \mathrm{~ns}$ & $306 \mathrm{~ns}$ & 2.85 & $0.02 \mathrm{~ns}$ & $3.27 \mathrm{~ns}$ \\
\hline Genotypes (G) & 30 & $414.08 * * *$ & $0.26^{* * *}$ & $0.06^{* * *}$ & $17966.1 * * *$ & $109.07 * * *$ & $5.47 * * *$ & $1072.92 * * *$ \\
\hline Crosses (C) & 22 & $108.03 * * *$ & $0.10 \mathrm{~ns}$ & $0.02 * * *$ & $4926^{* * *}$ & $24.91 * * *$ & $1.49 * * *$ & $344.71 * * *$ \\
\hline GCA & 7 & $237.71 * * *$ & $0.13 \mathrm{~ns}$ & $0.01 * * *$ & $10876.42 *$ & $31.33 * *$ & $1.42 * * *$ & $572.95 * * *$ \\
\hline SCA & 15 & $47.51 \mathrm{~ns}$ & $0.08 \mathrm{~ns}$ & $0.02 * * *$ & $2150 \mathrm{~ns}$ & $21.9 \mathrm{~ns}$ & $1.53^{* * *}$ & $238.2^{* * *}$ \\
\hline Location (Loc) & 2 & $20.4 \mathrm{~ns}$ & $0.41 * *$ & $0.00^{* * *}$ & $82455^{*}$ & $7.49 \mathrm{~ns}$ & $0.15^{*}$ & $174.98^{* * *}$ \\
\hline $\mathrm{G} \times \mathrm{Loc}$ & 60 & $57.81 * * *$ & $0.16^{* *}$ & $0.00^{* * *}$ & $7884 * * *$ & $14.97 * * *$ & $0.23^{* * *}$ & $66.82 * * *$ \\
\hline $\mathrm{GCA} \times \mathrm{Loc}$ & 14 & $8.67 * * *$ & $0.07 *$ & $0.00^{*}$ & $3693 * * *$ & $7.89 * * *$ & $0.00 \mathrm{~ns}$ & $18.05^{* * *}$ \\
\hline $\mathrm{SCA} \times \operatorname{Loc}$ & 30 & $24.73 * * *$ & $0.05^{*}$ & $0.00 * * *$ & $1715^{* * *}$ & $4.29 *$ & $0.06^{* * *}$ & $24.47 * * *$ \\
\hline $\mathrm{C} \times \mathrm{Loc}$ & 44 & $19.62 * * *$ & $0.06 * *$ & $0.00^{* * *}$ & $2344 * * *$ & $5.44 * * *$ & $0.52 * * *$ & $22.43 * * *$ \\
\hline Residual & 60 & 1.38 & 0.03 & 0.00 & 48.77 & 2.60 & 0.01 & 0.87 \\
\hline Bakers ratio & & 0.80 & 0.47 & 0.22 & 0.87 & 0.35 & 0.28 & 0.52 \\
\hline NSCGD & & 0.79 & 0.31 & 0.22 & 0.86 & 0.32 & 0.28 & 0.52 \\
\hline BSCGD & & 0.98 & 0.66 & 0.99 & 0.98 & 0.91 & 0.99 & 0.99 \\
\hline
\end{tabular}

Note. ${ }^{* * *}=$ significant at $0.001, * *=$ significant at $0.01, *=$ significant at 0.05 .

\subsection{Estimates of General Combining Ability (GCA) Effects}

Table 2. Estimates of general combining ability effects for eight parental lines

\begin{tabular}{|c|c|c|c|c|c|c|c|}
\hline & $\begin{array}{l}\text { Days to } 50 \% \\
\text { Flowering }\end{array}$ & $\begin{array}{l}\text { Leaf area } \\
\left(\mathrm{m}^{2}\right)\end{array}$ & Leaf-stem Ratio & $\begin{array}{l}\text { Plant height } \\
\text { (m) }\end{array}$ & $\begin{array}{l}1000 \text { Seed Wt } \\
(\mathrm{g})\end{array}$ & $\begin{array}{l}\text { Grain Yld } \\
\left(\text { ton } \text { ha }^{-1}\right)\end{array}$ & $\begin{array}{l}\text { Biomass } \\
\left(\text { ton ha }{ }^{-1}\right)\end{array}$ \\
\hline $22(\mathrm{~F})$ & -0.35 & 0.01 & $-0.03 * * *$ & 0.71 & 0.69 & $-0.10 * *$ & $1.98 * * *$ \\
\hline $24(\mathrm{~F})$ & $2.72 * * *$ & 0.04 & $-0.06 * * *$ & $43.55 * * *$ & 0.18 & $0.53 * * *$ & $11.37 * * *$ \\
\hline $29(\mathrm{~F})$ & $1.35 * * *$ & $0.16^{*}$ & $-0.01 *$ & $13.01 * * *$ & $1.97 * *$ & $-0.31 * * *$ & $5.94 * * *$ \\
\hline $34(\mathrm{~F})$ & $4.08 * * *$ & -0.04 & $0.04 * * *$ & 1.03 & 0.59 & $-0.17 * * *$ & $3.27 * * *$ \\
\hline $35(\mathrm{G})$ & $5.13 * * *$ & 0.05 & 0.00 & $22.77 * * *$ & 0.69 & $0.04 *$ & $0.99 *$ \\
\hline $41(\mathrm{G})$ & $-2.12 * * *$ & 0.01 & $-0.01 * *$ & $10.09 * *$ & 1.23 & $0.38 * * *$ & $4.76^{* * *}$ \\
\hline $20(\mathrm{G})$ & $-7.50 * * *$ & $-0.18^{*}$ & $0.04 * * *$ & $-38.63 * * *$ & $2.71 * * *$ & $0.07 *$ & $-9.53 * * *$ \\
\hline $42(\mathrm{G})$ & $-2.77 * * *$ & -0.07 & $0.02 * * *$ & $-45.61 * * *$ & 1.26 & $0.26 * * *$ & $6.63 * * *$ \\
\hline
\end{tabular}

Note. $(\mathrm{F})=$ Forage sorghum, $(\mathrm{G})=$ Grain sorghum, $* * *, * *, *=$ significant at $0.001,0.01$ and 0.05 respectively.

The estimates of general combining ability effects of parents for seven traits are presented in Table 2 . The significant $(\mathrm{P} \leq 0.05)$ GCA effects for parents 20 and 29 indicated that these lines were good combiners for 1000 seed weight. Significant $(\mathrm{P} \leq 0.05)$ estimates of GCA effects were observed for all parental lines except 22 for days to $50 \%$ flowering although only lines 20,41 , and 42 significantly $(\mathrm{P} \leq 0.001)$ reduced the flowering dates. Lines 20 and 29 had significant $(\mathrm{P} \leq 0.05)$ GCA for Leaf area although only line 29 contributed significantly $(\mathrm{P} \leq$ $0.05)$ to higher Leaf area in the crosses. Significant $(\mathrm{P} \leq 0.05)$ GCA effects for leaf-stem ratio were observed in all the lines except line 35. All the parental lines had significant GCA effects for Plant height, grain yield and biomass except lines 20 and 34 for grain yield and plant height respectively.

\subsection{Estimates of Specific Combining Ability Effects}

The estimates for specific combining ability are presented in Table 3. Significant non-additive effects were observed in some of the crosses. Of the five crosses that showed significant $(\mathrm{P} \leq 0.05)$ estimates of SCA effects only cross $41 \times 42$ was positive for 1000 seed weight. SCA effects were significant $(\mathrm{P} \leq 0.05)$ in 15 crosses for days to $50 \%$ flowering although reduction in flowering duration was only seen in 8 crosses. Only $42 \times 29$ cross showed significant $(\mathrm{P} \leq 0.001)$ non-additive effects for leaf area while all crosses but 3 showed significance $(\mathrm{P} \leq$ $0.05)$ for leaf- stem ratio with 9 showing positive $(\mathrm{P} \leq 0.05)$ significant effects. 10 crosses had significant $(\mathrm{P} \leq$ 
0.05) estimates of SCA effects for plant height. All but five crosses showed significant $(\mathrm{P} \leq 0.05)$ estimates of SCA effects for grain yield and biomass.Eight crosses had positive significant $(\mathrm{P} \leq 0.05)$ SCA effects.

Table 3. Estimates of specific combining ability effects

\begin{tabular}{|c|c|c|c|c|c|c|c|}
\hline Cross & $\begin{array}{l}\text { Days to } 50 \% \\
\text { Flowering }\end{array}$ & $\begin{array}{l}\text { Leaf area } \\
\left(\mathrm{m}^{2}\right)\end{array}$ & Leaf-stem Ratio & $\begin{array}{l}\text { Plant height } \\
\text { (m) }\end{array}$ & $\begin{array}{l}1000 \text { Seed Wt } \\
(\mathrm{g})\end{array}$ & $\begin{array}{l}\text { Grain Yld } \\
\left(\text { ton } \mathrm{ha}^{-1} \text { ) }\right.\end{array}$ & 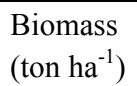 \\
\hline $22 \times 20$ & $-3.02 * *$ & -0.04 & $-0.10 * * *$ & 2.32 & -1.4 & 0.14 & $-2.73 * * *$ \\
\hline $24 \times 20$ & 1.66 & 0.02 & $0.07^{* * *}$ & 7.18 & 1.33 & $0.18^{*}$ & $7.04^{* * *}$ \\
\hline $29 \times 20$ & $-2.96^{* *}$ & -0.12 & $0.03 * * *$ & -8.28 & $-4.31 * *$ & -0.07 & $-9.03 * * *$ \\
\hline $29 \times 22$ & 0.67 & -0.09 & $-0.07 * * *$ & -10.22 & -0.36 & $-0.38 * * *$ & 1.06 \\
\hline $29 \times 24$ & 1.93 & -0.08 & 0.00 & 4.54 & 1.84 & $-1.03 * * *$ & $5.69^{* * *}$ \\
\hline $34 \times 20$ & -0.02 & 0.10 & $0.03 * * *$ & $-16.9 * *$ & 0.51 & $-0.64 * * *$ & 1.14 \\
\hline $34 \times 22$ & $-3.83 * * *$ & 0.11 & $-0.01 *$ & $31.47 * * *$ & 1.07 & $-0.52 * * *$ & 0.87 \\
\hline $34 \times 29$ & $4.46^{* * *}$ & -0.15 & $-0.05 * * *$ & 0.46 & 1.62 & $1.28 * * *$ & 1.45 \\
\hline $35 \times 20$ & $6.71 * * *$ & 0.10 & $-0.12 * * *$ & $56.65 * * *$ & 1.83 & $-0.43 * * *$ & $2.37 * *$ \\
\hline $35 \times 22$ & -0.55 & 0.01 & $0.08^{* * *}$ & $-41.78^{* * *}$ & -0.03 & $0.81^{* * *}$ & 0.38 \\
\hline $35 \times 24$ & -1.4 & -0.01 & $-0.08 * * *$ & $-28.53 * * *$ & $-3.09 *$ & $0.17 *$ & $1.73 *$ \\
\hline $35 \times 29$ & -1.11 & -0.01 & $0.10 * * *$ & 4.11 & 2.32 & $0.69 * * *$ & $-4.82 * * *$ \\
\hline $35 \times 34$ & 1.57 & 0.05 & $0.03 * * *$ & 5.6 & -2.05 & $-0.67 * * *$ & $4.50 * * *$ \\
\hline $41 \times 20$ & $-2.37 *$ & -0.06 & $0.09 * * *$ & $-40.97 * * *$ & 2.02 & $0.82 * * *$ & 1.21 \\
\hline $41 \times 22$ & $6.04 * * *$ & 0.10 & $-0.02 * *$ & $26.6^{* * *}$ & $4.01 * *$ & 0.13 & $8.54 * * *$ \\
\hline $41 \times 24$ & $-3.14 * *$ & 0.13 & $-0.03 * * *$ & $13.75^{*}$ & -2.04 & -0.04 & $-6.04 * * *$ \\
\hline $41 \times 29$ & $-4.66 * * *$ & -0.06 & $0.05 * * *$ & -6.01 & $-3.28 *$ & $-0.43 * * *$ & $-13.37 * * *$ \\
\hline $42 \times 22$ & 0.69 & -0.09 & $0.12 * * *$ & -8.39 & $-3.29^{*}$ & $-0.18^{*}$ & $-8.13 * * *$ \\
\hline $42 \times 24$ & 0.95 & -0.06 & $0.04 * * *$ & 3.06 & 1.96 & $0.73 * * *$ & $-8.42 * * *$ \\
\hline $42 \times 29$ & $1.65^{*}$ & $0.51 * * *$ & $-0.07 * * *$ & $15.4 * *$ & 2.17 & -0.05 & $19.02 * * *$ \\
\hline $42 \times 34$ & $-2.18^{*}$ & -0.11 & 0.00 & $-20.62 * * *$ & -1.15 & $0.54 * * *$ & $-7.97 * * *$ \\
\hline $42 \times 35$ & $-5.24 * * *$ & -0.13 & -0.01 & 3.94 & 1.02 & $-0.57 * * *$ & $-4.16 * * *$ \\
\hline $42 \times 41$ & $4.13 * * *$ & -0.12 & $-0.09 * * *$ & 6.62 & -0.71 & $-0.47 * * *$ & $9.66 * * *$ \\
\hline
\end{tabular}

\subsection{Performance of Crosses}

The estimates of mid and better parent heterosis for flowering duration, leaf-stem ratio, grain yield and biomass are presented in Table 4. An earlier flowering date is desirable than late flowering. Mid parent and better parent heterosis for days to $50 \%$ flowering ranged between -10 to $10 \%$ and from -8 to $13 \%$ respectively. The flowering duration of forage sorghums was reduced in majority of the crosses. A negative heterosis estimate for days to flowering is desirable because it implies that the crosses flowered earlier than the parents. Sixteen crosses were better than the mid-parent while only five surpassed the better- parent.

A higher leaf stem ratio is desirable when considering a crop as a feed. The mid-parent values ranged between -29 to $34 \%$ whereas the better parent heterosis estimate was between -32 to $33 \%$. Twelve crosses exhibited positive heterosis over the mid-parent. Some of the outstanding crosses were $29 \times 20,29 \times 24,34 \times 20,35 \times 29$, $41 \times 20,41 \times 29$, and $41 \times 22$ as they performed better than both the mid and better parent.

A positive heterosis value for grain yield is desirable because it implies that the crosses outperformed the parents. The mid-parent and better-parent heterosis ranged between -0.3 to $52 \%$ and -23 to $32 \%$ respectively. Fourteen out of the twenty three crosses performed better than the better parent.

A positive heterosis value was desirable for biomass and all the crosses exhibited heterosis over the mid parent by 4.1 to $82 \%$ while only 6 of the crosses performed below the better parent. 
Table 4. Estimates of mid-parent and better-parent heterosis (\%) for Days to 50\% flowering, leaf-Stem ratio, grain yield and biomass

\begin{tabular}{|c|c|c|c|c|c|c|c|c|}
\hline \multirow{2}{*}{ Cross } & \multicolumn{2}{|c|}{ Days to $50 \%$ Flowering } & \multicolumn{2}{|c|}{ Leaf-stem ratio } & \multicolumn{2}{|c|}{ Grain yield (ton $\mathrm{ha}^{-1}$ ) } & \multicolumn{2}{|c|}{ Biomass (ton $\mathrm{ha}^{-1}$ ) } \\
\hline & MP & $\mathrm{BP}$ & MP & $\mathrm{BP}$ & MP & $\mathrm{BP}$ & MP & $\mathrm{BP}$ \\
\hline $22 \times 20$ & -10.3 & 0.8 & -29.7 & -32.4 & 21.8 & -11.1 & 25.3 & 5.9 \\
\hline $24 \times 20$ & -1.8 & 10.9 & 34.1 & -3.2 & 34.3 & 8.8 & 63.1 & 15.0 \\
\hline $29 \times 20$ & -8.3 & 3.1 & 17.6 & 0.1 & -5.6 & -23.7 & 55.9 & 5.1 \\
\hline $29 \times 22$ & -6.2 & -6.1 & -18.5 & -28.3 & 15.0 & 0.4 & 30.3 & -2.0 \\
\hline $29 \times 24$ & -2.1 & -1.7 & 28.4 & 4.8 & -0.3 & -0.6 & 45.6 & 34.7 \\
\hline $34 \times 20$ & -3.1 & 10.5 & 6.4 & 3.6 & 10.5 & -6.4 & 13.2 & -16.5 \\
\hline $34 \times 22$ & -9.2 & -8.0 & -12.6 & -18.2 & 37.6 & 14.5 & 46.3 & 23.6 \\
\hline $34 \times 29$ & 1.0 & 2.3 & -4.5 & -20.5 & 21.7 & 15.0 & 18.2 & 2.4 \\
\hline $35 \times 20$ & 8.9 & 20.6 & -23.9 & -29.9 & 7.2 & 1.3 & 39.5 & 28.4 \\
\hline $35 \times 22$ & -2.2 & -0.8 & 11.4 & -1.7 & 36.2 & -1.0 & 69.8 & 54.6 \\
\hline $35 \times 24$ & -0.3 & 1.6 & -11.7 & -32.6 & 30.4 & 1.2 & 67.9 & 24.9 \\
\hline $35 \times 29$ & -1.0 & 0.4 & 38.5 & 27.0 & 12.6 & 12.7 & 5.9 & -25.1 \\
\hline $35 \times 34$ & 3.4 & 6.2 & 6.2 & -4.6 & 7.6 & 13.0 & 60.8 & 25.9 \\
\hline $41 \times 20$ & -3.5 & -0.6 & 32.1 & 11.7 & 33.6 & 23.1 & 39.4 & 15.9 \\
\hline $41 \times 22$ & 3.7 & 13.0 & -6.6 & -18.3 & 49.7 & 15.7 & 72.5 & 25.6 \\
\hline $41 \times 24$ & -3.7 & 5.5 & 15.6 & -5.1 & 52.2 & 32.1 & 40.7 & -10.6 \\
\hline $41 \times 29$ & -6.5 & 1.9 & 34.7 & 33.7 & 2.6 & -11.1 & 11.9 & -31.1 \\
\hline $42 \times 22$ & -1.5 & 9.3 & 16.8 & 12.6 & 49.5 & 0.1 & 14.4 & 2.1 \\
\hline $42 \times 24$ & 1.8 & 13.6 & 22.5 & -11.4 & 46.4 & 6.7 & 4.1 & -23.7 \\
\hline $42 \times 29$ & 1.5 & 12.7 & -11.2 & -24.2 & 16.1 & -15.5 & 75.3 & 22.4 \\
\hline $42 \times 34$ & -1.2 & 11.3 & -2.6 & -5.5 & 40.8 & 6.4 & 44.4 & 11.3 \\
\hline $42 \times 35$ & -0.6 & 8.8 & -2.5 & -10.0 & 11.6 & 2.0 & 7.9 & 10.3 \\
\hline $42 \times 41$ & 9.5 & 11.4 & -16.5 & -29.2 & 33.3 & 8.1 & 81.5 & 43.6 \\
\hline
\end{tabular}

Note. $\mathrm{MP}=$ Mid-parent, BP Better-parent.

\section{Discussion}

\subsection{Performance of Parental Lines and Crosses across Locations}

Combining analysis of variance over the three locations confirmed the diversity of the genotypes and their differences in locational responses. The significant $(\mathrm{P} \leq 0.05)$ interactions for majority of the traits indicated the differences of genotypes in environmental responses for the traits. Similar observations were made by Girma et al. (2010). Analysis of the crosses for seven traits indicated that most genetic variation for each trait measured was associated with significant $(\mathrm{P} \leq 0.05)$ general combining ability effects except for leaf area. However, the significant $(\mathrm{P} \leq 0.05) \mathrm{SCA}$ effects for leaf stem ratio, grain yield and biomass indicated that non-additive effects were also important for the three traits. Nevertheless, for traits where the mean squares of GCA were larger than SCA, even with significant SCA such as biomass, the role of the additive genetic effects was more important.Flowering duration, 1000 seed weight, and plant height were largely governed by additive gene action.Girma et al. (2010) reported similar results for seed weight. Environmental effects could have played a major role on Leaf area as neither additive nor non additive effects were significant. The bakers ratio was moderate to high for leaf area, biomass, days to 50\% flowering and plant height indicating the preponderance of additive gene effects in the variance expressed as these were also the traits that had higher GCA mean squares values. The closer the bakers ability ratio is to unity, the larger the importance of additive genetic control, and hence, the greater the capacity to predict the performance of progeny based exclusively on GCA effects (Baker, 1978).

\subsection{Estimates of General Combining Ability}

The primary criteria for selection of desirable parents are usually based on mean values and additive gene action (Nguyen et al., 1997). Girma et al. (2010) suggested that crossing two parents showing the highest general combining ability for a desirable trait may produce the best performing cross due to an increased frequency of 
favorable genes. Based on the estimates of GCA effects, it was observed that parental lines 20 and 29 would be the best combiners for 1000 seed weight. Only the grain sorghums contributed to reducing the flowering days because of the negative significant GCA estimates suggesting that the grain sorghums generally tended to flower earlier than the forage sorghums owing to their inherent genetic makeup. This makes grain sorghums useful in reducing the flowering date of forage sorghums. Neither additive nor non-additive effects were statistically significant for Leaf area in the analysis of variance possibly because it was derived from the leaf parameters which were largely influenced by the environment. However, parental line 29 showed significant estimate of GCA implying that it was a good combiner for the leaf area. Girma et al. (2010) reported significant estimates of GCA for leaf area in some of the induced sorghum mutants. The estimates of GCA for leaf-stem ratio indicated that lines 20, 34 and 42 were the best combiners for this trait because of the positive GCA. Lines 24, 35 and 41 were the best combiners for both plant height and grain yield due to the positive significant $(\mathrm{P} \leq 0.05)$ GCA estimates.All the parental lines had positive significant $(\mathrm{P} \leq 0.05) \mathrm{GCA}$ effects for biomass except lines 20 and 35 which had negative GCA estimates indicating that theses two were not the best for this trait. Similar results were reported for fodder yield and its components by Prakash et al. (2010).

Lines 29, 41 and 42 were generally good combiners for four different traits out of seven traits while lines 20 and 35 were good general combiners for at least three different traits. However, lines 24,41 and 42 were the best general combiners for grain yield and biomass due to the positive significant GCA effects. The superior combining ability of best combiners could be exploitedin hybrid or recurrent selection programmes. Additive variance is associated with effective response to selection (Valiolla, 2012) hence small numbers of parents with desired GCAs can be used to generate crossesfor sorghum improvement.

\subsection{Estimates of Specific Combining Ability}

The performance of a cross can deviate from the average general combining ability of two parental lines and this deviation is referred to as specific combining ability. Only Cross $41 \times 22$ out of the twenty three crosses had positive significant $(\mathrm{P} \leq 0.01)$ estimate of SCA effects for 1000 seed weight implying that GCA effects were more important for this trait. Nguyen et al. (1997) reported similar findings for 100 seed weight. The estimates of SCA for leaf-stem ratio were significant $(\mathrm{P} \leq 0.05)$ in twenty out of twenty three crosses but only nine crosses were desirable as they had positive SCA estimates. Although this trait was controlled by both additive and non additive gene action, SCA effects had a slightly higher influence as observed from the slightly larger mean square value than GCA (Table 1). Of the eighteen crosses that showed significant $(\mathrm{P} \leq 0.05)$ estimates for grain yield and biomass only eight crosses had positive significant estimates for SCA suggesting that non additive effects were important for these two traits. Mwije et al. (2014) indicated that parents with the best GCA effects did not necessarily produce crosses with desirable SCA effects as was observed in this study.From Table 1, the mean sum of squares of SCA for grain yield was higher than that of GCA although both were significant $(\mathrm{P} \leq$ 0.001 ) because grain yield is a complex trait which results from the contribution of many grain yield components each adding varying levels of genetic effects (Umakanth et al., 2002). The heritability estimate of below $30 \%$ (Table 1) implied that yield could not be enhanced through direct effects alone.Biomass was, however, largely controlled more by additive gene action.

\subsection{Performance of Crosses}

Superior cross combinations could be selected based on heterosis. Quantitative genetic theory states that heterosis is a function of increasing genetic diversity among the parents (Falconer, 1989). More than half the number of crosses resulting from the grain and forage sorghums were characterized by heterosis over the mid-parent for days to $50 \%$ flowering, leaf-stem ratio, grain yield and biomass although it varied from cross to cross. The expression of such value of heterosis clearly indicated the agronomic potential of these lines for breeding to enhance grain and forage yield. The results of this study indicated that heterosis could be exploited and that different parental combinations (grain by forage, forage by grain) showed high specific combining ability thus indicating the role of dominance gene action. These results clearly showed that both inter and intra allelic interactions were involved in the expression of the traits.

\section{References}

Baker, R. J. (1978). Issues in diallel analysis. Crop Science, 18, 533-536. https://doi.org/10.2135/cropsci1978. 0011183X001800040001x

Bawazir, A. A. (2009). Genetic Analysis for Yield and Yield Components in Grain Sorghum (Sorghum bicolor L.). Jordan Journal of Agricultural Sciences, 5, 273-281.

Bernardo, R. (2014). Essentials of plant breeding. Stemma Press, Woodbury, Minnesota. 
Chakauya, E., Tongoona, P., Matiburi, E. A., \& Grum, M. (2006). Genetic diversity assessment of sorghum landraces in Zimbabwe using microsatellites and indigenous local names. International Journal of Botany, 2 , 29-35. https://doi.org/10.3923/ijb.2006.29.35

Griffing, B. (1956). Concept of general and specific combining ability in relation to diallel crossing systems. Journal of Biological Sciences, 9, 463-493. https://doi.org/10.1071/bi9560463

Girma, M., Ayana, A., \& Belete, K. (2010). Combining ability of yield and its components in Ethiopian sorghum landraces. East African Journal of Sciences, 4(1), 34-40.

Falconer, S. P. (1989). Introduction to quantitative genetics. New York: The Ronald Press Company.

Falconer, D. S., \& Mackay, T. F. C. (1996). Quantitative genetics (4th ed., p. 464). Longman Group Limited. UK.

IBPGR/ICRISAT. (1993). Descriptors for sorghum (Sorghum bicolor (L.) Moench). International Board for Plant Genetic Resources, Rome, Italy; International Crops Research Institute for Semi-Arid Tropics, Patancheru, India.

Jain, S. K., \& Patel, P. R. (2014). Combining ability and heterosis for grain yield, fodder yield and other agronomic traits in sorghum (Sorghum bicolor (L) Moench). Journal of Plant Breeding, 5(2), 152-157.

Prakash, R., Ganesamurthy, K., Nirmalakumari, A., \& Nagarajan, P. (2010). Combining ability for fodder yield and its components in Sorghum (Sorghum bicolor L. Moench). Electron. Journal of Plant Breeding, 1, 124-128.

Nadarajan, N., \& Gunasegaram, M. (2005). Quantitative genetics and biometrical techniques in plant breeding (p. 258). Kalyani Publishers, New Delhi, India.

Nguyen, D. C., Nakamura, S., \& Yoshida, T. (1997). Combining ability and genotype by environment interaction in early maturing grain sorghum for summer seeding. Japan Journal of Crop Science, 66(4), 34-40.

Mativavarira, M., Dimes, J., Masikati, P., Van Rooyen, A., Mwenje, E., Sikosana, J. L. N., \& Tui, S. H. K. (2011). Evaluation of water productivity, stover feed quality and farmers' preferences on sweet sorghum cultivar types in the semi-arid regions of Zimbabwe. Journal of SAT Agricultural Research, 9(1), 1-9.

Mwije, A., Mukasa, S. B., Gibson, P., \& Kyamanya, S. (2014). Heritability analysis in putative drought adaptation traits in sweet potato. African Crop Science Journal, 22(1), 79-87.

Rai, K. N., Murty, D. S., Andrews, D. J., \& Bramel-Cox, P. J. (1999). Genetic enhancement of pearl millet and sorghum for the semi-arid tropics of Asia and Africa. Genome, 42, 617-628. https://doi.org/10.1139/g99-040

Sibanda, A., Homann-KeeTui, S., Van Rooyen, A., Dimes, J., Nkomboni, D., \& Sisito, G. (2011). Understanding user communities' perception of changes in rangeland use and productivity: Evidence from Nkayi district, Zimbabwe. Experimental Agriculture, 47(S1), 153-168. https://doi.org/10.1017/S001447971000092X

Singh, R. K., \& Chaudhary, B. D. (1985). Biometrical Methods in Quantitative Genetic Analysis (p. 318). Kalyani Publishers, New Delhi, India.

Umakanth, A. V., Madhusudhana, K., Madhavi Latha, P., Hema, K., \& Kaul, S. (2002). Genetic architecture of yield and its contributing characters in postrainy-season sorghum. International Sorghum and Millets Newsletter, 44, 37-40.

Valiolla, R. (2012). Combining ability analysis of plant height and yield components in spring type of rapeseed varieties (Brassica napus L.) using line $\times$ tester analysis. International Journal of Agriculture and Forestry, 2(1), 58-62. https://doi.org/10.5923/j.ijaf.20120201.10

VSN International. (2011). GenStat for Windows (14th ed.). VSN International, Hemel Hempstead, UK.

Williams, T. O., Fernandez-Rivera, S., \& Kelley, T. G. (1997). The influence of socio economic factors on the availability and utilization of crop residues as animal feeds. In C. Renard (Ed.), Proceedings of the International Workshop on Crop Residues in Sustainable Mixed Crop-Livestock Farming Systems (pp. 25-39), April 22-26, 1996, Patancheru, India. CAB International, Wallingford.

Yan, W., \& Hunt, L. A. (2002). Biplot analysis of diallel data. Crop Science Journal, 42, 21-30. https://doi.org/10.1201/9781420040371.ch9 


\section{Copyrights}

Copyright for this article is retained by the author(s), with first publication rights granted to the journal.

This is an open-access article distributed under the terms and conditions of the Creative Commons Attribution license (http://creativecommons.org/licenses/by/4.0/). 